\title{
YIELD AND FATTY ACID COMPOSITION OF BLACK CUMIN (Nigella sativa L.) POPULATIONS COLLECTED FROM REGIONS UNDER DIFFERENT ECOLOGICAL CONDITIONS
}

\author{
CAN, M. $.^{*}-$ KATAR, D. ${ }^{2}-$ KATAR, ${ }^{3}{ }^{3}-$ BAGCI, M. ${ }^{4}-$ SUBASI, I. ${ }^{4}$ \\ ${ }^{1}$ Agriculture and Forestry Provincial Directorate, Uşak, Turkey \\ ${ }^{2}$ Eskisehir Osmangazi University, Faculty of Agriculture, Eskisehir, Turkey \\ ${ }^{3}$ Agriculture and Forestry Provincial Directorate, Eskisehir, Turkey \\ ${ }^{4}$ Dept. of Oilseeds Breeding, Central Research Institute for Field Crops, Ankara, Turkey \\ *Corresponding author \\ e-mail: mustafican@gmail.com; phone: +90-276-231-1504; fax: +90-276-231-1500 \\ (Received $3^{\text {rd }}$ Nov 2020; accepted $8^{\text {th }}$ Feb 2021)
}

\begin{abstract}
This study aimed to reveal the effect of different genotypes (population and variety) on yield, yield components and quality parameters of black cumin (Nigella sativa L.). The experiment was carried out in the Aegean Region of Turkey in two vegetation seasons of 2017 and 2018. In the study, four black cumin populations (Uşak, Hatay, Diyarbakır and Burdur) obtained from Turkey's different regions as well as Çameli variety were used. The plant materials had been cultivated in a randomized complete block design with three replications. Results showed that there were statistically significant differences among genotypes in terms of all parameters examined except for fixed oil ratio. The mean seed yield varied between $0.34-0.86 \mathrm{t} \mathrm{ha}^{-1}$ in 2017 and $0.10-0.31 \mathrm{t} \mathrm{ha}^{-1}$ in 2018. The seed and fixed oil yields were higher for Çameli, Hatay and Diyarbakır genotypes. The percentages of linoleic and oleic acid of genotypes varied in a range of $55.85-57.67 \%$ and $21.05-22.59 \%$, respectively. There was no significant difference among genotypes in terms of linoleic acid content. However, a significant difference was found among genotypes in terms of oleic acid content and the oleic acid content was higher in the black cumin populations than the Çameli variety.
\end{abstract}

Keywords: genotypes, fixed oil, linoleic acid, oleic acid, palmitic acid

\section{Introduction}

Black cumin (Nigella sativa L.), one of the most important species belonging to Ranunculaceae family, is an annual herbaceous medicinal plant (Thilakarathna et al., 2018). It is a plant distributed within the natural flora of Eastern Mediterranean, Southern Europe and Central Asia (Wajs et al., 2008). There are 12 species (Nigella orientalis L., Nigella sativa L., $N$. oxypetala L., $N$. latisecta P.H. Davis, $N$. segetalis Bieb., $N$. arvensis L., $N$. damascena L., N. elata Boiss., N. nigellastrum (L.) Willk., N. unguicularis (Lam.) Spenner ve $N$. lancifolia Hub. -Mor.) of Nigella genus in the flora of Turkey. However, only $N$. sativa and $N$. damascena are cultivated in different regions of Turkey (Toncer and Kizil, 2004; Baydar, 2013).

Black cumin is known as one of the cultivated plants that have been used for different purposes since ancient times. Its seeds and oil have been used in traditional medicine for hundreds of years, especially in Asia and Africa. In today's medicine, its seeds are used in the treatment of different diseases due to their stimulating effect. In the future, it is thought that its seeds and oil will occupy an important place in alternative medicine due to its protective effect in both the treatment of and in the prevention of various diseases (Abdolrahimi et al., 2012). The part of the plant used in food and alternative medicine is its 
seed (Gun, 2012). Black cumin seeds have been used as a spice for many years in many parts of the world, especially in the Middle East and India (Kara et al., 2015; Thilakarathna et al., 2018).

In addition, these seeds have been used in the food industry to decorate bakery products and add taste and flavor to the products. Fixed oils and essential oils from black cumin seeds are an important source of raw materials for the pharmaceutical and cosmetics industry (Hussain et al., 2009). The seeds of the plant have been used in folk medicine for thousands of years in the treatment of asthma, cough, bronchitis, headache, rheumatism, fever, flu, eczema. Seeds are also used in the treatment of obesity, kidney disorders, digestive diseases and in the regulation of blood circulation (Abdolrahimi et al., 2012; Thilakarathna et al., 2018).

Fixed oil and essential oils of black cumin in alternative medicine systems in recent years; It is used to take advantage of the activities of antibacterial, antifungal, cholesterol regulating, antitumor, calming, soothing, pain relief, lowering blood sugar, antiemetic and relaxing smooth muscles (Nivkavar et al., 2003). Studies conducted on black cumin showed that its seeds have essential oils (0.30-0.60\%), fixed oils (35-40\%), proteins (16-21\%), amino acids, saponins, alkaloids, tannins, fibers (5.5\%), carbohydrates (35\%) minerals (1.79-3.44\%), thymoquinone (a phenolic compound found in essential oil), ascorbic acid (vitamin C), thiamine, niacin, pyridoxine and folic acid (Hussain et al., 2009; Ghamarnia et al., 2012; Gullu and Avci, 2013; Shaker et al., 2014).

It is known that thymoquinone, an important bioactive substance of black cumin, has an anti-carcinogenic effect (Padhye et al., 2008). Most of the researchers stated that the fixed oil rate of black cumin varies between $25 \%$ and $40 \%$ (Sener et al., 1985; Ustun et al., 1990; Nergiz and Otles, 1993; Ghorbanli et al., 2000; Matthaus and Ozcan, 2011; Kara et al., 2015). When the fatty acid composition of the oil was examined, it was seen that approximately $84-85 \%$ of the oil consisted of oleic (27\%) and linoleic (57\%) acids. In addition, black cumin oil contains low rates of eicosadienoic, arachidonic and linolenic acid, known as unsaturated fatty acids. Fixed oil of black cumin seeds has also saturated fatty acids such as myristic, palmitic and stearic acid (Gullu and Avci, 2013). Amin et al. (2010) reported that the major fatty acids of black cumin oil was linoleic acid (50.2\%), oleic acid (19.9\%), margaric acid (10.3\%), cis-11,14-eicosadienoic acid (7.7\%) and stearic acid (2.5\%). Sener et al. (1985) stated that the fixed oil of black cumin seeds contains $0.26 \%$ lauric, $1.06 \%$ myristic, $20.4 \%$ palmitic, $1.56 \%$ stearic, $4.75 \%$ oleic, $64.6 \%$ linoleic and $7.18 \%$ arachidonic acid.

As it is known, many factors are effective in the growth and development of plants (Katar and Katar, 2017). These factors are generally divided into two as intrinsic and extrinsic factors (Janina, 2003). Intrinsic factors are controlled by the genetic makeup of plants (Franz, 1993). Therefore, the growth and development performances of plants with various inherited characteristics differ with the effect of their genes (Hussain et al., 2006).

Black cumin is generally cultivated under dry farming conditions. Growing black cumin under these conditions often results in low seed yield and quality losses due to limited rainfall, the requirement to compete with weeds, etc. İt can vary yield and quality due to variation in genetic and ecological influence in different regions cultivated of black cumin. Thus, geographical and genetic diversity are extremely important in respect to yield and quality characteristics of black cumin. One of the most crucial factors to achieve higher yield and quality in agriculture is the selection of suitable genotype adapted to the region. Native plant populations generally adapt better to regional conditions. Therefore, it should be determined the yield and quality potential of these populations under various ecological 
conditions. The effect of black cumin genotypes on yield, yield components and quality characters was examined by some researchers (Nickavar et al., 2003; Abdolrahimi et al., 2012; Hosseinia et al., 2018). However, each of these studies was conducted with different genotypes under different ecological conditions.

Therefore, in this study conducted in Turkey where black cumin production increasingly in recent years, it was aimed to reveal the performances of different black cumin genotypes (population and variety) in terms of yield, yield components and quality parameters.

\section{Material and methods}

\section{Experimental location}

The experiments were carried out under the ecological conditions of Uşak province located in the Aegean Region of Turkey during 2017 and 2018 growing seasons. Uşak province is located between $38^{\circ} 12$ 'and $39^{\circ} 50^{\prime} \mathrm{N}$ latitudes and $28^{\circ} 48^{\prime}$ and $29^{\circ} 57^{\prime} \mathrm{E}$ longitudes with $907 \mathrm{~m}$ altitude. Location of the working area was shown in Figure 1.

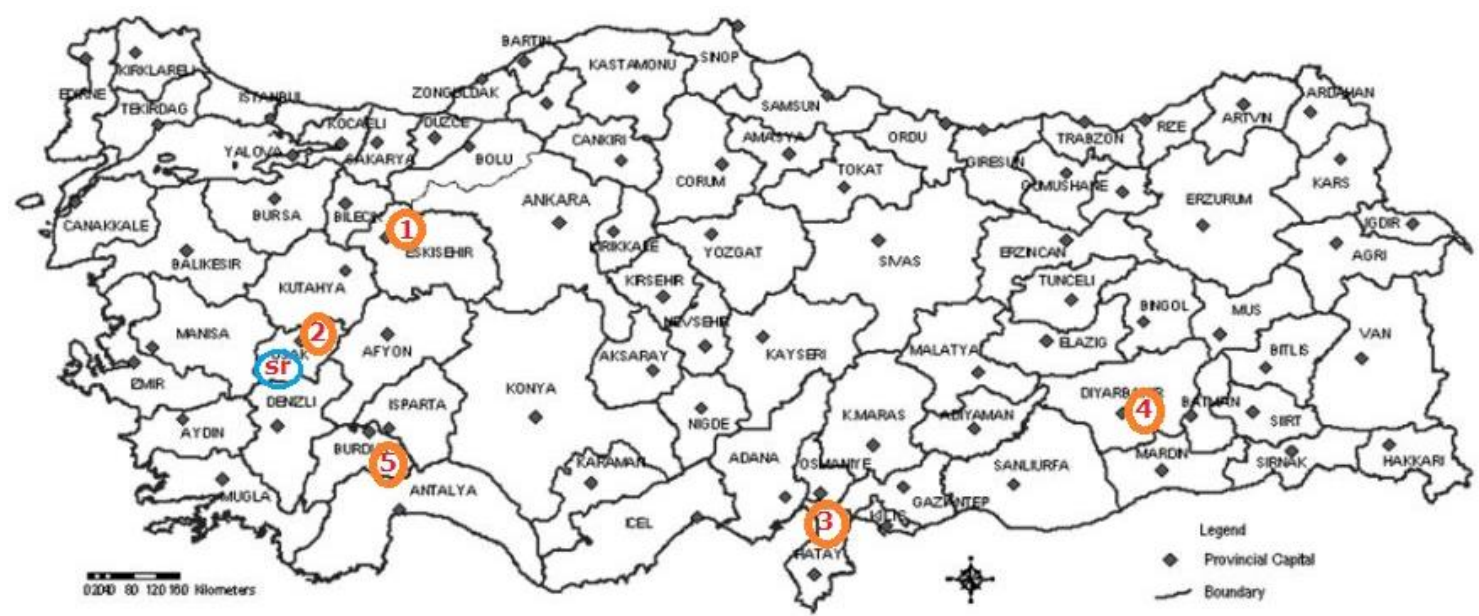

Figure 1. Locations of genotypes collected and study region in map of Turkey (1: Çameli, 2: Uşak, 3: Hatay, 4: Diyarbakır, 5: Burdur, sr: study region)

\section{Climatic data of the experimental site}

The climate of the Usak province has a transition characteristic between the Aegean and Central Anatolia regions. The climate is warm and temperate in Usak. The winter months are much rainier than the summer months in province. The province was characterized by semi-arid climate with a mean annual precipitation of $567 \mathrm{~mm}$ and mean temperature of $12.5^{\circ} \mathrm{C}$. In the growing period at the experimental site, total precipitation is $269.3 \mathrm{~mm}$ in 2017 and $336.2 \mathrm{~mm}$ in 2018. For the same growing period (March-August) at the experimental site, the total rainfall for long years is $216.3 \mathrm{~mm}$. April 2018 precipitation $(6.4 \mathrm{~mm})$ was very low compared to the same month in 2017 $(62.9 \mathrm{~mm})$. Mean air temperatures were $17.3^{\circ} \mathrm{C}, 18.4^{\circ} \mathrm{C}$ and $16.9^{\circ} \mathrm{C}$ during the cropping period in 2017, 2018 and long years, respectively. In addition, the mean relative humidity values were $54.4 \%, 55.6 \%$ and $57.4 \%$ during the cropping periods in 2017 , 2018 and long years, respectively (Table 1). 
Table 1. Meteorological data of the experiment location

\begin{tabular}{|c|c|c|c|c|c|c|c|c|}
\hline \multirow{2}{*}{$\begin{array}{c}\text { Climatic } \\
\text { factors }\end{array}$} & \multirow{2}{*}{ Years } & \multicolumn{6}{|c|}{ Months } & \multirow{2}{*}{ Mean/Sum } \\
\hline & & March & April & May & June & July & August & \\
\hline Total & 2017 & 37.1 & 62.9 & 100.2 & 42.3 & 1.2 & 25.6 & 269.3 \\
\hline Precipitation & 2018 & 76.8 & 6.4 & 102.4 & 54.6 & 58.2 & 37.8 & 336.2 \\
\hline$(\mathrm{mm})$ & LYA* & 54.6 & 61.6 & 46.2 & 25.8 & 17.2 & 10.9 & 216.3 \\
\hline Mean & 2017 & 8.3 & 11.1 & 15.1 & 20.1 & 25.1 & 24.0 & 17.3 \\
\hline Temperature & 2018 & 9.3 & 15.4 & 17.2 & 20.2 & 23.7 & 24.3 & 18.4 \\
\hline$\left({ }^{\circ} \mathrm{C}\right)$ & LYA & 6.4 & 11.0 & 15.7 & 20.3 & 24.0 & 24.1 & 16.9 \\
\hline Mean & 2017 & 59.7 & 56.4 & 61.9 & 58.7 & 41.4 & 48.2 & 54.4 \\
\hline Relative Humidity & 2018 & 67.6 & 47.5 & 61.5 & 59.4 & 49.3 & 48.0 & 55.6 \\
\hline$(\%)$ & LYA & 67.1 & 64.0 & 61.1 & 55.1 & 48.9 & 48.2 & 57.4 \\
\hline
\end{tabular}

*LYA: Long-years average (1986-2016)

\section{Soil properties}

The soil samples $(0-30 \mathrm{~cm}$ depth) were taken from various parts of the experimental area and the collected soil samples were homogeneously mixed. Then, the mixed soil samples were analyzed to determine physicochemical properties of soil. The results indicated that the soils were clay-loam with $\mathrm{pH} 7.81-7.88$ and 9.9-11.4\% lime. Furthermore, it was found that the soil contains low organic matter (0.88-1.71\%), low $\mathrm{P}_{2} \mathrm{O}_{5}\left(2.46-1.20 \mathrm{~kg} \mathrm{ha}^{-1}\right)$ and high $\mathrm{K}_{2} \mathrm{O}\left(340-360 \mathrm{~kg} \mathrm{ha}^{-1}\right)$. The soil, in which the second year of the experiment was conducted, contains more organic matter than the soil of first year. However, it contains slightly more lime than the soil of first year (Table 2).

Table 2. Some physical and chemical characteristics of the experimental soil

\begin{tabular}{c|c|c|c|c|c|c}
\hline Years & Texture & $\begin{array}{c}\text { Lime } \\
(\mathbf{\%})\end{array}$ & $\begin{array}{c}\text { Available } \\
\mathbf{p h o s p h o r u s} \\
\left(\mathbf{P}_{\mathbf{2}} \mathbf{O}_{\mathbf{5}} \mathbf{( \mathbf { k g ~ h a } ^ { - 1 } )}\right.\end{array}$ & $\begin{array}{c}\text { Available } \\
\mathbf{p o t a s s i u m} \\
\left(\mathbf{K}_{\mathbf{2}} \mathbf{O}\right) \mathbf{( \mathbf { k g ~ h a } ^ { - 1 } )}\end{array}$ & $\mathbf{p H}$ & $\begin{array}{c}\text { Organic } \\
\mathbf{m a t t e r} \\
\mathbf{( \% )}\end{array}$ \\
\hline 2017 & Clay-Loam & 9.9 & 2.46 & 340 & 7.81 & 0.88 \\
2018 & Clay-Loam & 11.4 & 1.20 & 360 & 7.88 & 1.71 \\
\hline
\end{tabular}

\section{Experimental conditions}

In the study, four populations obtained from farmers in Turkey's Usak, Hatay, Diyarbakır and Burdur provinces and Cameli variety obtained from Transitional Zone Agricultural Research Institute, Turkey were used as plant material. Location of collected genotypes was marked in Figure 1. The experimental design was a randomized complete block design with three replications. Seeds were sown by hand, with $25 \mathrm{~cm}$ row spacing on plots of $5 \mathrm{~m}^{2}$ harvest area (1 m width x $5 \mathrm{~m}$ length) on 25 March of 2017 and 22 March of 2018. Seeding was performed with a seeding rate of 15 $\mathrm{kg} \mathrm{ha}^{-1}$ and sowing depth of 2-3 cm (Hussain et al., 2009; Haj Seyed Hadi et al., 2012; Kara et al., 2015). Each plot was $5 \mathrm{~m}$ length and consisted of 4 rows. In both years, it was done by hand when weed control of the experimental area was need. No irrigation was applied. The experimental plots were fertilized with a dose of $50 \mathrm{~kg} \mathrm{~N}$ and $30 \mathrm{~kg}$ $\mathrm{P}_{2} \mathrm{O}_{5}$ per ha (Hussain et al., 2009; Tuncturk et al., 2011; Ghamarnia et al., 2012). A photograph of the study area was presented in Figure 2. At the harvest, two border rows of the plots and $0.5 \mathrm{~m}$ from each side were excluded to eliminate border effects and then the plants in the plots were harvested by hand on the dates indicated in Table 3. 


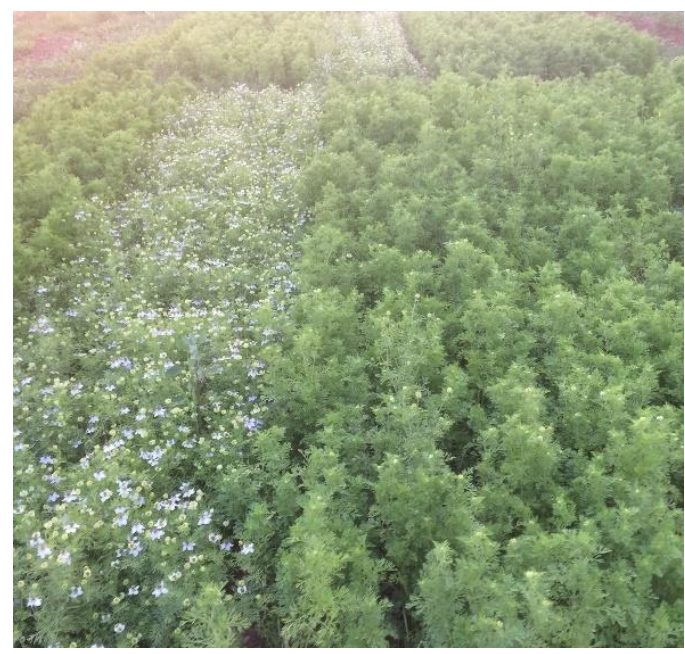

Figure 2. A photo of the experimental area

Table 3. Harvest times of black cumin genotypes

\begin{tabular}{c|c|c}
\hline Genotypes & $\mathbf{2 0 1 7}$ & $\mathbf{2 0 1 8}$ \\
\hline Çameli & 13.08 .2017 & 11.08 .2018 \\
Uşak & 12.08 .2017 & 11.08 .2018 \\
Hatay & 05.08 .2017 & 04.08 .2018 \\
Diyarbakır & 29.07 .2017 & 28.07 .2018 \\
Burdur & 12.08 .2017 & 11.08 .2018 \\
\hline
\end{tabular}

\section{Fixed oil}

The oil contents and compositions were determined in the laboratories of the Central Research Institute for Field Crops of the Ministry of Agriculture and Forestry, in Ankara, Turkey. Determination of the oil contents was performed following the method of Matthäus and Brühl (2001), with some modifications. Next, 5 grams of whole seeds were milled in a Foss KN 195 Knifetec laboratory mill (Hillerød, Denmark). Afterwards, the extraction was performed for $3 \mathrm{~h}$ in a Soxhlet extractor (Soxtherm 2000 automatic, Gerhardt, Germany) with hexane. After extraction, the solvent was evaporated at $103^{\circ} \mathrm{C}$ for $2.5 \mathrm{~h}$, cooled for $30 \mathrm{~min}$ in a desiccator, and weighed. The seed oil content was reported as the mass percent (crude oil weight (g)/ground seeds weight $(\mathrm{g}) \times 100)$. For determination of the fatty acid compositions, $0.1 \mathrm{~g}$ of oil was dissolved in $10 \mathrm{~mL} \mathrm{n}$-hexane, to which $0.5 \mathrm{~mL} 2 \mathrm{~N}$ potassium hydroxide/methanol solution was added, and it was incubated for $30 \mathrm{~min}$ at room temperature. The fatty acids were esterified as methyl esters and placed to a Shimadzu AOC-20i automatic Injector (Kyoto, Japan) (split ratio 1:100). The methyl ester phase was analyzed using a Shimadzu GC-2010 system equipped with a Teknokroma capillary column (Barcelona, Spain) $(100 \mathrm{~m} \times 0.25 \mathrm{~mm}$ and $0.2 \mu \mathrm{m})$ and FID detector. Helium was used as carrier gas at a flow rate of $0.94 \mathrm{~mL} / \mathrm{min}$. The injector and detector temperature was $250^{\circ} \mathrm{C}$. The column was programmed with the following temperature regime: hold at $140^{\circ} \mathrm{C}$ for 5 min, ramp to $240^{\circ} \mathrm{C}$ at $4^{\circ} \mathrm{C} / \mathrm{min}$, and hold at $240^{\circ} \mathrm{C}$ for $20 \mathrm{~min}$. Fatty acid methyl esters (FAMEs) were identified by comparison of their retention times with those of the reference standards (Restek FAME Mix 37). The fatty acid content was calculated based on the peak area ratio and expressed as $\mathrm{g}$ fatty acid/100 $\mathrm{g}$ of oil. 


\section{Statistical analysis}

With randomized complete block design, analytical data collected with three replications of each treatment were subjected to analysis of variance using SPSS statistical software program, and differences among mean values were compared via the Tukey (Tukey's Honest Significant Difference test) test.

\section{Results}

The plant heights of black cumin genotypes varied according to genotypes, years and genotype by year interaction. In compared to genotypes, maximum plant heights (39.17, $38.84,38.15$ and $36.45 \mathrm{~cm}$ ) were counted on the genotypes of Burdur, Cameli, Hatay and Usak, respectively. Mean plant height value in the first year $(46.80 \mathrm{~cm})$ were higher than that of the second year $(25.75 \mathrm{~cm})$ (Table 4).

The number of branches per plant of black cumin genotypes varied according to genotypes and genotype by year interaction. By comparing mean values of genotypes, the highest numbers of branches per plant (3.74 and 3.22) were obtained from the genotypes of Cameli and Usak, respectively. As it can be seen from Table 4, statistical significant differences were not observed between years for the numbers of branches per plant. In 2017, the highest number of branches per plant was determined in Usak (3.40), Hatay (3.37) and Cameli (3.08) genotypes in the same group, while in 2018 it was determined in Cameli (4.40) genotype (Table 4).

The capsule number values of genotypes varied according to genotypes, years and genotype by year interaction. According to the two-year mean, the number of capsules per plant ranged from 3.24 to 4.45 and the highest values were determined in Cameli and Burdur genotypes. According to the mean of genotypes, the number of capsules per plant was 4.74 in 2017 and 3.02 in 2018 . According to the genotype by year interaction values, the highest values were determined in Burdur (5.43) and Hatay (5.03) genotypes in 2017, while it was obtained from Çameli genotype (4.43) in 2018 (Table 4).

The genotypes, years, and genotype by year interaction had a significant effect on seed weight per capsule. As the mean of genotypes, the seed weight per capsule was $0.23 \mathrm{~g}$ in 2017 and $0.12 \mathrm{~g}$ in 2018 . As the mean of two-year, the seed weight per capsule ranged from 0.13 to $0.21 \mathrm{~g}$ and the highest values were determined in Hatay and Çameli genotypes. Considering the values of genotype by year interaction, the highest values in 2017 were obtained from Hatay $(0.28 \mathrm{~g})$ and Uşak $(0.25 \mathrm{~g})$ genotypes. On the other hand, in 2018, the second year of the study, the highest values were obtained from Hatay (0.14 g), Çameli (0.14 g), Uşak (0.11 g) and Burdur (0.11 g) genotypes (Table 4).

Only a significant difference among genotypes was detected in terms of 1000 seed weight. As the mean of two-year, 1000 seed weight values ranged between 1.98-2.39 g and the highest values were obtained from Hatay (2.39 g), Uşak (2.19 g) and Diyarbakır $(2.14 \mathrm{~g})$ genotypes (Table 4).

The genotypes, years, and genotype by year interaction had a significant effect on seed yield $\left(\mathrm{t} \mathrm{ha}^{-1}\right)$. While mean seed yield was $0.67 \mathrm{t} \mathrm{ha}^{-1}$ in 2017 , it was $0.23 \mathrm{t} \mathrm{ha}^{-1}$ in 2018. As the mean of two-year, the seed yield ranged from 0.30 to $0.55 \mathrm{t} \mathrm{ha}^{-1}$ and the highest values were determined in Hatay $\left(0.55 \mathrm{t} \mathrm{ha}^{-1}\right)$, Çameli $\left(0.52 \mathrm{t} \mathrm{ha}^{-1}\right)$ and Diyarbakır $\left(0.48 \mathrm{tha}^{-1}\right)$ genotypes. Considering the genotype values with the year interaction, the highest values in 2017 were obtained from Diyarbakir, Hatay and Çameli genotypes as $0.86 \mathrm{t} \mathrm{ha}^{-1}, 0.79 \mathrm{t} \mathrm{ha}^{-1}$ and $0.75 \mathrm{t} \mathrm{ha}^{-1}$ respectively (Table 4). On the 


$$
-1331 \text { - }
$$

other hand, the highest values in 2018 were obtained from the Hatay, Çameli and Burdur genotypes as $0.31 \mathrm{t} \mathrm{ha}^{-1}, 0.30 \mathrm{t} \mathrm{ha}^{-1}$ and $0.26 \mathrm{t} \mathrm{ha}^{-1}$ respectively (Table 4).

Table 4. Yield, yield components and fixed oil rate of black cumin genotypes

\begin{tabular}{|c|c|c|c|c|c|c|}
\hline \multirow{2}{*}{ Genotypes } & \multicolumn{3}{|c|}{ Plant height $(\mathbf{c m})$} & \multicolumn{3}{|c|}{ Number of branches per plant } \\
\hline & 2017 & 2018 & Mean & 2017 & 2018 & Mean \\
\hline Çameli & $49.50 \mathrm{a}$ & $28.17 \mathrm{a}$ & $38.84 \mathrm{a}$ & $3.08 \mathrm{ab}$ & $4.40 \mathrm{a}$ & $3.74 \mathrm{a}$ \\
\hline Uşak & $47.90 \mathrm{a}$ & $25.00 \mathrm{ab}$ & $36.45 \mathrm{a}$ & $3.40 \mathrm{a}$ & $3.03 \mathrm{~b}$ & $3.22 \mathrm{a}$ \\
\hline Hatay & $50.97 \mathrm{a}$ & $25.33 \mathrm{ab}$ & $38.15 \mathrm{a}$ & $3.37 \mathrm{a}$ & $2.20 \mathrm{c}$ & $2.79 \mathrm{~b}$ \\
\hline Diyarbakır & $34.93 \mathrm{~b}$ & $22.60 \mathrm{~b}$ & $28.77 \mathrm{~b}$ & $2.78 \mathrm{~b}$ & $2.30 \mathrm{c}$ & $2.54 \mathrm{~b}$ \\
\hline Burdur & $50.70 \mathrm{a}$ & $27.63 \mathrm{a}$ & $39.17 \mathrm{a}$ & $2.85 \mathrm{~b}$ & $2.71 \mathrm{bc}$ & $2.78 \mathrm{~b}$ \\
\hline Mean & $46.80 \mathrm{~A}$ & $25.75 \mathrm{~B}$ & 36.27 & 3.10 & 2.93 & 3.01 \\
\hline $\mathrm{CV}(\%)$ & \multicolumn{3}{|c|}{32.48} & \multicolumn{3}{|c|}{21.59} \\
\hline Year & \multicolumn{3}{|c|}{$* *$} & \multicolumn{3}{|c|}{ ns } \\
\hline Genotypes & \multicolumn{3}{|c|}{$* *$} & \multicolumn{3}{|c|}{$* *$} \\
\hline Y x G & \multicolumn{3}{|c|}{$* *$} & \multicolumn{3}{|c|}{$* *$} \\
\hline \multirow{2}{*}{ Genotypes } & \multicolumn{3}{|c|}{ Number of capsule per plant } & \multicolumn{3}{|c|}{ Seed weight per capsule (g) } \\
\hline & 2017 & 2018 & Mean & 2017 & 2018 & Mean \\
\hline Çameli & $4.47 \mathrm{bc}$ & $4.43 \mathrm{a}$ & $4.45 \mathrm{a}$ & $0.23 \mathrm{bc}$ & $0.14 \mathrm{a}$ & $0.19 \mathrm{ab}$ \\
\hline Uşak & $4.55 \mathrm{bc}$ & $3.47 \mathrm{~b}$ & $4.01 \mathrm{~b}$ & $0.25 \mathrm{ab}$ & $0.11 \mathrm{ab}$ & $0.18 \mathrm{bc}$ \\
\hline Hatay & $5.03 \mathrm{ab}$ & $2.23 \mathrm{c}$ & $3.63 \mathrm{bc}$ & $0.28 \mathrm{a}$ & $0.14 \mathrm{a}$ & $0.21 \mathrm{a}$ \\
\hline Diyarbakır & $4.20 \mathrm{c}$ & $2.28 \mathrm{c}$ & $3.24 \mathrm{c}$ & $0.18 \mathrm{c}$ & $0.08 \mathrm{c}$ & $0.13 \mathrm{~d}$ \\
\hline Burdur & $5.43 \mathrm{a}$ & $2.67 \mathrm{c}$ & $4.05 \mathrm{ab}$ & $0.20 \mathrm{c}$ & $0.11 \mathrm{ab}$ & $0.16 \mathrm{~cd}$ \\
\hline Mean & $4.74 \mathrm{~A}$ & $3.02 \mathrm{~B}$ & 3.88 & $0.23 \mathrm{~A}$ & $0.12 \mathrm{~B}$ & 0.17 \\
\hline $\mathrm{CV}(\%)$ & \multicolumn{3}{|c|}{29.15} & \multicolumn{3}{|c|}{35.29} \\
\hline Year & \multicolumn{3}{|c|}{$* *$} & \multicolumn{3}{|c|}{$* *$} \\
\hline Genotypes & \multicolumn{3}{|c|}{$* *$} & \multicolumn{3}{|c|}{$* *$} \\
\hline Y x G & \multicolumn{3}{|c|}{$* *$} & \multicolumn{3}{|c|}{$* *$} \\
\hline & & 0 seed w & (g) & & eed yield & \\
\hline Genotypes & 2017 & 2018 & Mean & 2017 & 2018 & Mean \\
\hline Çameli & 1.89 & 2.16 & $2.03 \mathrm{~b}$ & $0.75 \mathrm{a}$ & $0.30 \mathrm{a}$ & $0.52 \mathrm{a}$ \\
\hline Uşak & 2.08 & 2.29 & $2.19 \mathrm{ab}$ & $0.59 \mathrm{~b}$ & $0.20 \mathrm{~b}$ & $0.39 \mathrm{~b}$ \\
\hline Hatay & 2.47 & 2.31 & $2.39 \mathrm{a}$ & $0.79 \mathrm{a}$ & $0.31 \mathrm{a}$ & $0.55 \mathrm{a}$ \\
\hline Diyarbakır & 2.20 & 2.07 & $2.14 \mathrm{ab}$ & $0.86 \mathrm{a}$ & $0.10 \mathrm{c}$ & $0.48 \mathrm{a}$ \\
\hline Burdur & 2.03 & 1.92 & $1.98 \mathrm{~b}$ & $0.34 \mathrm{c}$ & $0.26 \mathrm{a}$ & $0.30 \mathrm{c}$ \\
\hline Mean & 2.13 & 2.15 & 2.14 & $0.67 \mathrm{~A}$ & $0.23 \mathrm{~B}$ & 0.45 \\
\hline $\mathrm{CV}(\%)$ & & 10.2 & & & 59.54 & \\
\hline Year & & $\mathrm{ns}$ & & & $* *$ & \\
\hline Genotypes & & $* *$ & & & $* *$ & \\
\hline $\mathrm{Y} \times \mathrm{G}$ & & $\mathrm{ns}$ & & & $* *$ & \\
\hline Genotynes & & xed oil ra & & & d oil yield & $\left.\mathrm{ha}^{-1}\right)$ \\
\hline Genotypes & 2017 & 2018 & Mean & 2017 & 2018 & Mean \\
\hline Çameli & $33.62 \mathrm{ab}$ & $34.95 \mathrm{a}$ & 34.29 & $250.00 \mathrm{a}$ & $104.20 \mathrm{a}$ & $177.1 \mathrm{a}$ \\
\hline Uşak & $32.34 \mathrm{~b}$ & $33.01 \mathrm{a}$ & 32.68 & $190.20 \mathrm{~b}$ & $65.10 \mathrm{c}$ & $127.7 \mathrm{~b}$ \\
\hline Hatay & $31.34 \mathrm{~b}$ & $33.15 \mathrm{a}$ & 32.25 & $249.10 \mathrm{a}$ & $97.00 \mathrm{a}$ & $173.1 \mathrm{a}$ \\
\hline Diyarbakır & $31.54 \mathrm{~b}$ & $34.46 \mathrm{a}$ & 33.00 & $272.00 \mathrm{a}$ & $34.50 \mathrm{~d}$ & $153.3 \mathrm{a}$ \\
\hline Burdur & $35.55 \mathrm{a}$ & $31.37 \mathrm{a}$ & 33.46 & $120.10 \mathrm{c}$ & $81.10 \mathrm{~b}$ & $100.6 \mathrm{c}$ \\
\hline Mean & 32.88 & 33.39 & 33.13 & $216.30 \mathrm{~A}$ & $76.40 \mathrm{~B}$ & 146.3 \\
\hline $\mathrm{CV}(\%)$ & & 6.71 & & & 57.49 & \\
\hline Year & & $\mathrm{ns}$ & & & $* *$ & \\
\hline Genotypes & & ns & & & $* *$ & \\
\hline Y x G & & $*$ & & & $* *$ & \\
\hline
\end{tabular}

*: $\mathrm{P}<0.05$, **: $\mathrm{P}<0.01, \mathrm{Y}$ : Year, G: Genotypes, ns: Not significant, CV: Coefficient of variation. Means in the same columns followed by the different small letters and in the same rows followed by the different capital letters are significantly different as statistically 
No statistically significant difference was determined among the fixed oil rates of black cumin genotypes used in this study. Genotype by year interaction had a significant effect on fixed oil rate. The highest fixed oil rates were determined in Burdur $(35.55 \%)$ and Çameli (33.62\%) genotypes in 2017. No statistically significant difference was found among genotypes in terms of fixed oil rate in 2018. The fixed oil rate of $33.13 \%$ was determined as the mean value of two-year and genotypes (Table 4).

The genotypes, years, and genotype by year interaction had a significant effect on fixed oil yield $\left(\mathrm{L} \mathrm{ha}^{-1}\right)$. While mean fixed oil yield was $216.30 \mathrm{~L} \mathrm{ha}^{-1}$ in 2017 , It was $76.40 \mathrm{~L} \mathrm{ha}^{-1}$ in 2018. As the mean of two-year, the fixed oil yield ranged from 100.6 to 177.1 $\mathrm{L} \mathrm{ha}^{-1}$ and the highest value were determined in Çameli $\left(177.1 \mathrm{~L} \mathrm{ha}^{-1}\right)$, Hatay (173.1 L ha ${ }^{-1}$ ) and Diyarbakır (153.3 $\mathrm{L} \mathrm{ha}^{-1}$ ) genotypes. Diyarbakır, Hatay and Çameli genotypes were the genotypes with the highest fixed oil yield in 2017. On the other hand, the highest fixed oil yield in 2018 was obtained from the Çameli and Hatay genotypes as 104.20 $\mathrm{L} \mathrm{ha}^{-1}$ and 97.00 $\mathrm{L} \mathrm{ha}^{-1}$, respectively (Table 4).

The content of total unsaturated fatty acids (palmitoleic, oleic, linoleic, arachidonic, linolenic and cis-11,14-eicosadienoic) of black cumin genotypes ranged from $81.03 \%$ to $82.41 \%$, whereas saturated fatty acids (caproic, palmitic and stearic) were 16.2617.27\%. In addition, linoleic (55.85-57.67\%), oleic (21.05-22.59\%) and palmitic (11.16-12.24\%) were found to be the major fatty acids. The highest linoleic acid content was obtained from the Çameli variety $(57.67 \%)$. However, no significant difference was found among genotypes in terms of linoleic acid content. On the other hand, the oleic acid content of the Çameli variety was significantly lower than the other genotypes. In addition, the four populations examined in the study were not significantly different in terms of oleic acid content (Table 5).

Table 5. Fatty acids components of black cumin genotypes

\begin{tabular}{c|ccccc|cc}
\hline $\begin{array}{c}\text { Fatty acids } \\
(\%)\end{array}$ & Çameli & Uşak & Hatay & Diyarbakır & Burdur & \multirow{2}{*}{ Mean } \\
\hline Caproic Acid (C6:0) & 1.74 & 2.08 & 1.22 & 1.90 & 1.53 & 1.70 & n.s. \\
Palmitic Acid (C16:0) & 11.16 & 11.32 & 11.98 & 11.25 & 12.24 & 11.59 & n.s. \\
Palmitoleic Acid (C16:1) & 0.15 & - & 0.15 & - & 0.16 & 0.15 & n.s. \\
Stearic Acid (C18:0) & 3.36 & 3.55 & 3.42 & 3.34 & 3.50 & 3.44 & n.s. \\
Oleic Acid (C18:1n9c) & $21.05 \mathrm{~b}$ & $21.94 \mathrm{ab}$ & $22.59 \mathrm{a}$ & $21.72 \mathrm{ab}$ & $21.85 \mathrm{ab}$ & 21.83 & $*$ \\
Linoleic Acid (C18:2n6c) & 57.67 & 56.43 & 55.85 & 56.85 & 56.14 & 56.59 & n.s. \\
Arachidonic Acid (20:4. $\omega-6)$ & 0.21 & - & 0.21 & 0.19 & 0.20 & 0.20 & n.s. \\
Linolenic Acid (C18:3n6) & 0.32 & 0.30 & 0.30 & 0.31 & 0.29 & 0.30 & n.s. \\
Cis-11.14-Eicosadienoic Acid (C20:2) & $3.01 \mathrm{a}$ & $3.08 \mathrm{a}$ & $2.62 \mathrm{~b}$ & $3.08 \mathrm{a}$ & $2.39 \mathrm{ab}$ & 2.83 & $* *$ \\
\hline Total & 98.65 & 98.71 & 98.34 & 98.63 & 98.29 & & \\
\hline
\end{tabular}

*: $\mathrm{P}<0.05, * *: \mathrm{P}<0.01$, n.s.: Not significant. Means in the same rows followed by the different small letters are significantly different as statistically

\section{Discussion}

\section{Yield and yield components}

As the environmental conditions move away from the ideal conditions for optimum growth and development of each plant; yield and quality losses increase (Amin et al., 2010; Goksoy et al., 2019). The variation in yield and yield components detected in the study depending on the years can be explained by the extreme drought experienced in April 2018. Since the seeds sowed on March 22, 2018 were faced with an extreme 
drought immediately after emergence (in April), the initial growth and development of the plants were limited. Although the precipitation returned to normal in the following months, this growth and development retardation experienced in April caused the values obtained in 2018 to be lower compared to 2017. Also, the variation in the yield and yield components due to genotypes can be attributed to the difference in the genetic makeup of the plant materials used in the study.

Different yield response of cultivars/varietis from one environment to another is called genotype by environment (GEI) interaction (Goksoy et al., 2019). The fact that genotypes showed different values in yield and yield components in 2017 and 2018 can be explained by the response of genotypes to changing climatic conditions. Genotypes were negatively affected by drought in 2018, resulting in a decrease in yield and yield components. It was stated that the seed yield and components of black cumin decreased rapidly due to the increasing water stress during the growth periods in semi-arid climatic conditions (Ghamarnia and Jalili, 2013). In addition, Sadeghi (2009) reported that there was a positive correlation between seed yield and aboveground biomass. In the study, seed yields of black cumin genotypes varied according to years and genotypes. This difference between two years can be explained by the extreme drought in April 2018. This drought negatively affected the growth performance of the plant during the first development period and caused significant decreases in the values of the yield and yield components in 2018. The yield difference detected among genotypes can be attributed to the different inherited make up of genotypes. The Hatay and Diyarbakir populations used in the study and obtained from warmer regions are more early populations than the others (Table 3). It has been reported that yield of early genotypes may be higher due to their better use of available moisture in semi-arid and arid climatic conditions in a study conducted on wheat genotypes (Ludwig and Asseng, 2010). D'Antuono et al. (2002) reported that the main factor reducing yield for black cumin genotypes seemed low vegetative growth. These results were lower than those of Ozel et al. (2009), Tuncturk et al. (2012) and Kara et al. (2015). These differences are thought to be due to probably variations in genotype, environmental conditions, agronomic practices. In addition, it has been reported that the environmental conditions during pollination determine the number of capsules and branches (Sadeghi, 2009).

\section{Fixed oil rate}

There was no difference in fixed oil rate between the two years in which the study was conducted. This showed that the plant materials used in the study were not very different from each other in terms of genetic inheritance that determined the oil content. Matthaus and Ozcan (2011) determined that the fixed oil rate of black cumin seeds vary between $30.4 \%$ and $36.4 \%$. Kara et al. (2015) reported that the fixed oil rates of black cumin populations collected from the Burdur, Tokat, Uşak, Eskişehir and Antalya provinces were $24.5 \%, 30.6 \%, 30.5 \%, 25.6 \%$ and $30.4 \%$, respectively. Results from this study are similar with the Matthaus and Ozcan (2011) findings but was higher than Kara et al. (2015). Differing findings among studies in terms of fixed oil rate can be probably due to genotype, growing, localities, climatic and environmental conditions (Matthaus and Ozcan, 2011; Hendawy et al., 2012).

\section{Fatty acid compositions}

While the variation of linoleic acid among genotypes is $3.26 \%$, the variation of oleic acid is $7.32 \%$. The variation in palmitic acid, which is another major fatty acid, was 
found to be $9.68 \%$. That is, genotypes showed the highest variation in palmitic acid in terms of fatty acid composition. It is desired that palmitic, which is a saturated fatty acid in terms of fat quality, is low and oleic acid, which is a monounsaturated fatty acid, is also high. While Çameli genotype stood out in terms of low palmitic acid, the variation among Çameli (78.72\%), Usak (78.37\%), Hatay (78.44\%) and Diyarbakır $(78.57 \%)$ genotype was very low in terms of the sum of oleic and linoleic acids. As a result, genotypes were generally found to be similar in terms of fatty acid composition. Ustun et al. (1990) reported that the linoleic acid contents of black cumin seeds collected from the Kutahya, Denizli and Konya provinces were $61.84 \%, 62.53 \%$, and $58.38 \%$, respectively. Also, Matthaus and Ozcan (2011) determined that the linoleic acid contents of black cumin seeds vary between $56.7 \%$ and $58.9 \%$. Some researchers have found that the oleic acid contents of black cumin seeds vary between $18.7 \%$ and $23.7 \%$ (Ustun et al., 1990; Matthaus and Ozcan, 2011). The differences among the fatty acid composition reported in previous studies and the values obtained in this study can be explained by the different climatic conditions of the regions where the experiments carried out, as well as the difference among the genotypes studied (Amin et al., 2010; Gullu and Avci, 2013).

\section{Conclusions}

According to the results of this study that with five genotypes obtained from different regions of Turkey conducted two years, yield and its components of black cumin were significantly affected by plant genotypes. On the other hand, no significant difference was found among the genotypes in terms of linoleic acid (the major fatty acid) content. However, genotypes differed significantly in terms of oleic acid (the second fatty acid) content. The oleic acid content of the Çameli variety was significantly lower than the other genotypes. Considering the results of this study conducted under Turkey's Uşak ecological conditions, Hatay, Çameli and Diyarbakır genotypes can be recommended for the region in terms of high seed and oil yield. When the composition of oil as well as the yield of black cumin was evaluated together, the favorite genotypes were Hatay and Diyarbakır genotypes. It is thought that the results obtained from this research will be a data especially for future black cumin breeding studies. Considering that the effects of climate change will be felt more in the future, it would be extremely beneficial to test different black cumin populations (native) more in terms of traits such as competition with weeds, drought resistance and cold resistance under dry farming conditions. Therefore, it should be to increase the breeding studies on black cumin plant.

\section{REFERENCES}

[1] Abdolrahimi, B., Mehdikhani, P., Hassanzadeh Gort Tappe, A. (2012): The effect of harvest index, yield and yield component of three varieties of black cumin (Nigella sativa L.) in different planting densities. - International Journal of AgriScience 2(1): 93-101.

[2] Amin, S., Mir Showkat, R., Kohli, K., Ali, B., Ali, M. (2010): A study of the chemical composition of black cumin oil and its effect on penetration enhancement from transdermal formulations. - Natural Product Research 24(12): 1151-7.

[3] Baydar, H. (2013): Medical, aromatic and delightful plants science and technology. Suleyman Demirel University, Publication No: 51, Isparta, Turkey. 
[4] D’Antuono, L. F., Moretti, A., Antonio, F. S. (2002): Seed yield, yield components, oil content and essential oil content and composition of Nigella sativa L. and Nigella damascena L. - Industrial Crops and Products 15: 59-69.

[5] Franz, C. H. (1993): Genetics. - In: Hay, R. K. M., Waterman, P. G. (eds.) Volatile Oil Crops. London: Longman Group UK Limited.

[6] Ghamarnia, H., Khosravy, H., Sepehri, S. (2012): Yield and water use efficiency of (Nigella sativa L.) under different irrigation treatments in semi-arid region in the west of Iran. - Journal of Medicinal Plants Research 4(16): 1612-1616.

[7] Ghamarnia, H., Jalili, Z. (2013): Water stress effects on different black cumin (Nigella sativa L.) components in a semi-arid region. - Int. J. of Agronomy and Plant Production 4(4): 753-762.

[8] Ghorbanli, M., Babai, A., Sepehr, M. F. (2000): The effect of water stress on the seed oil of Nigella sativa L. - Journal Essential Oil Research 12: 36-38.

[9] Goksoy, A. T., Sincik, M., Erdogmus, M., Ergin, M., Aytac, S., Gumuscu, G., Gunduz, O., Keles, R., Bayram, G., Senyigit, E. (2019): The parametric and non-parametric stability analyses for interpreting genotype by environment interaction of some soybean genotypes. - Turk Journal Field Crops 24(1): 28-38.

[10] Gullu, E. B., Avci, G. (2013): Thymoquinone: The bioactive component of Nigella sativa. - Kocatepe Veterinary Journal 6(1): 51-61.

[11] Gun, M. (2012): Holly seed: Nigella sativa (black cumin). Some knowledge corresponding to Nigella sativa's therapy ailment. - Mersin University School of Medicine Lokman Hekim Journal of History of Medicine and Folk Medicine 2(1): 43-46.

[12] Haj Seyed Hadi, M., Darzi, M. T., Ghandehari, Z. (2012): Effect of irrigation treatment and Azospirillum inoculation on yield and yield component of black cumin (Nigella sativa L.). - Journal Medicinal Plants Research 6(30): 4553-4561.

[13] Hendawy, S. F., El-Sherbeny, S. E., Hussein, M. S., Khalid, K. A., Ghazal, G. M. (2012): Response of two species of black cumin to foliar spray treatments. - Australian J. of Basic and Applied Sciences 6(10): 636-642.

[14] Hosseinia, S. S., Nadjafia, F., Asarehb, M. H., Rezadoost, H. (2018): Morphological and yield related traits, essential oil and oil production of different landraces of black cumin (Nigella sativa) in Iran. - Scientia Horticulturae 233: 1-8.

[15] Hussain, A., Anjum, F., Rab, A., Sajid, M. (2006): Effects of nitrogen on the growth and yield of asparagus (Asparagus officinalis). - Journal of Agricultural and Biological Science 2: 41-47.

[16] Hussain, A., Nadeem, A., Ashraf, I., Awan, M. (2009): Effect of weed competion periods on the growth and yield of black cumin (Nigella sativa L.). - Pakistan Journal of Weed Science Research 15(1): 71-81.

[17] Janina, M. S. (2003): Melissa officinalis. - The Int. J. Aromatherapy 10: 132-139.

[18] Kara, N., Katar, D., Baydar, H. (2015): Yield and quality of black cumin (Nigella sativa L.) populations: The effect of ecological conditions. - Turkish Journal of Field Crops 20(1): 9-14

[19] Katar, D., Katar, N. (2017): Effect of sowing rates in different row spacing on the yield and yield components of false flax (Camelina sativa (L.) Crantz). - Journal of Agricultural Faculty of Gaziosmanpasa University 34(1): 76-85.

[20] Ludwig, F., Asseng, S. (2010): Potential benefits of early vigor and changes in phenology in wheat to adapt to warmer and drier climates. - Agriculture Systems 103: 127-136.

[21] Matthäus, B., Brühl, L. (2001): Comparison of different methods for the determination of the oil content in oilseeds. - Journal of the American Oil Chemists' Society 78(1): 95102.

[22] Matthaus, B., Ozcan, M. M. (2011): Fatty acids, tocopherol, and sterol contents of some Nigella species seed oil. - Czech J. Food Science 29(2): 145-150.

[23] Nergiz, C., Otles, S. (1993): Chemical composition of Nigella sativa L. seeds. - Food Chemistry 48: 259-261. 
[24] Nickavar, B., Mojab, F., Javidnia, K., Amoli, M. A. R. (2003): Chemical composition of the fixed and volatile oils of Nigella sativa L. from Iran. - Zeitschrift fur Naturforschung 58(9-10): 629-631.

[25] Ozel, A., Demirel, U., Guler, I., Erden, K. (2009): Effect of different row spacing and seeding rate on black cumin (Nigella sativa L.) yields and some agricultural characters. Harran Uni. J. of Agriculture Faculty 13(1): 17-25. (in Turkish).

[26] Padhye, S., Banerjee, S., Ahmad, A., Mohammad, R., Sarkar, F. H. (2008): From here to eternity-the secret of pharaohs: Therapeutic potential of black cumin seeds and beyond.Cancer Ther. 6(b): 495-510.

[27] Sadeghi, S., Rahnavard, A., Ashrafi, Z. Y. (2009): Study importance of sowing date and plant density effect on black cumin yield. - Botany Research International 2(2): 94-98.

[28] Sener, B., Kusmenoğlu, S., Mutlugil, A., Bingol, F. (1985): A study with the seed of Nigella sativa. - Gazi Uni. J. of Pharmacy Faculty 2(1): 1-8.

[29] Shaker, A. H., Jamal, A. T., Sajid, O. M. (2014): Effect of watery and alcoholic medicinal plants extractions on in-vitro ruminant digestibility. - KSU Doga Bil. Derg. 17(3): 30-33.

[30] Thilakarathna, R. C. N., Madhusankha, G. D. M. P., Navaratne, S. B. (2018): Morphological characteristics of black cumin (Nigella sativa) seeds. - Chemistry Research Journal 3(3): 40-45.

[31] Toncer, O., Kizil, S. (2004): Effect of seed rate on agronomic and technologic characters of Nigella sativa L. - International Journal of Agriculture \& Biology 3: 529-532.

[32] Tuncturk, R., Tuncturk, M., Ciftci, V. (2012): The effects of varying nitrogen doses on yield and some yield components of black cumin (Nigella sativa L.). - Advances in Environmental Biology 6(2): 855-858.

[33] Ustun, G., Kent, L., Cekin, N., Civelekoglu, H. (1990): Investigation on the technological properties of Nigella sativa (black cumin) seed oil. - J. American Oil Chemical Society 67: 958-960.

[34] Wajs, A., Bonikowski, R., Kalemba, D. (2008): Composition of essential oil from seeds of Nigella sativa L. cultivated in Poland. - Flavour and Fragrance Journal 23: 126-132. 